\title{
A transition zone complex of ciliopathy proteins regulates ciliary composition
}

\author{
JF Reiter ${ }^{*}$, F Garcia-Gonzalo, K Corbit, W Dowdle, L Yee \\ From First International Cilia in Development and Disease Scientific Conference (2012) \\ London, UK. 16-18 May 2012
}

\begin{abstract}
We have identified a complex of proteins that form part of the transition zone, a region at the base of the cilium. This complex includes the three members of the Tectonic family, extracytosolic glycoproteins that interact with transmembrane components of the transition zone such as Tmem67, Tmem216, and Tmem231. These transmembrane proteins connect to an intracellular transition zone complex comprised of many known Joubert- and Meckelassociated proteins including Cc2d2a, B9d1, B9d2, Mks1. Loss of components of this transition zone complex in mice compromise ciliogenesis in some tissues, and deregulate ciliary protein composition in others. In particular, the ciliary localization of Smoothened (Smo), a central component of the Hedgehog pathway, depends on this complex. As Smo functions at the cilium, many mouse transition zone mutants show deregulation of Hh signaling, resulting in ventralization of the neural tube and polydactyly. Defining the components of the transition zone has led to the identification of additional genes underlying Joubert and Meckel syndromes including Tctn1, Tctn2 and B9d2. We hypothesize that Joubert and Meckel syndromes are caused by transition zone dysfunction that disrupts intercellular signaling, leading to developmental defects.
\end{abstract}

Submit your next manuscript to BioMed Central and take full advantage of:

- Convenient online submission

- Thorough peer review

- No space constraints or color figure charges

- Immediate publication on acceptance

- Inclusion in PubMed, CAS, Scopus and Google Scholar

- Research which is freely available for redistribution 